\title{
Corrigendum: What Controls the Orientation of TADF Emitters?
} Bilal A. Naqvi ${ }^{1}$, Markus Schmid ${ }^{1}$, Ettore Crovini ${ }^{2}$, Prakhar Sahay ${ }^{1}$, Tassilo Naujoks ${ }^{1}$,
Francesco Rodella ${ }^{3}$, Zhen Zhang ${ }^{4}$, Peter Strohriegl ${ }^{3}$, Stefan Bräse ${ }^{4,5}$, Eli Zysman-Colman ${ }^{2}$
and Wolfgang Brütting ${ }^{1 *}$

${ }^{1}$ Institute of Physics, University of Augsburg, Augsburg, Germany, ${ }^{2}$ Organic Semiconductor Centre, EaStCHEM School of Chemistry, University of St Andrews, St Andrews, United Kingdom, ${ }^{3}$ Macromolecular Chemistry, University of Bayreuth, Bayreuth, Germany, ${ }^{4}$ institute of Organic Chemistry, Karlsruhe Institute of Technology, Karlsruhe, Germany, ${ }^{5}$ Institute of Biological and Chemical Systems - Functional Molecular Systems, Karlsruhe Institute of Technology, Eggenstein-Leopoldshafen, Germany

Keywords: OLEDs, TADF, emitter orientation, molecular orientation, emitter-host interaction

\section{A corrigendum on}

What Controls the Orientation of TADF Emitters?

by Naqvi B. A., Schmid M., Crovini E., Sahay P., Naujoks T., Rodella F., Zhang Z., Strohriegl P., Bräse S., Zysman-Colman E., and Brütting W. (2020). What Controls the Orientation of TADF Emitters? Front. Chem. 8:750. doi: 10.3389/fchem.2020.00750

OPEN ACCESS

Edited by:

Guigen $L i$

Texas Tech University, United States

Reviewed by: Bo Jiang,

Jiangsu Normal University, China

*Correspondence: Wolfgang Brütting bruetting@physik.uni-augsburg.de

Specialty section: This article was submitted to

Organic Chemistry, a section of the journal Frontiers in Chemistry

Received: 23 November 2020 Accepted: 07 January 2021 Published: 17 February 2021

Citation:

Naqvi BA, Schmid M, Crovini $E$, Sahay $P$, Naujoks $T$, Rodella $F$,

Zhang Z, Strohriegl P, Bräse $S$, Zysman-Colman $E$ and Brütting $W$ (2021) Corrigendum: What Controls the Orientation of TADF Emitters? Front. Chem. 9:632639. doi: $10.3389 /$ fchem.2021.632639
In the original article, there was a mistake in Supplementary Figure S8 of the Supplementary Material, and derived from that, in Table $\mathbf{1}$ as well as Figures 7A, 8A as published. The measured values of the GSP for two of the host materials, viz. BCPO and $\mathrm{PO}_{9}$, were interchanged by mistake. These values also resulted in a wrong calculation of the degree of PDM alignment $(\Lambda)$. The corrected Table 1 as well as Figures 7A, 8A are attached below.

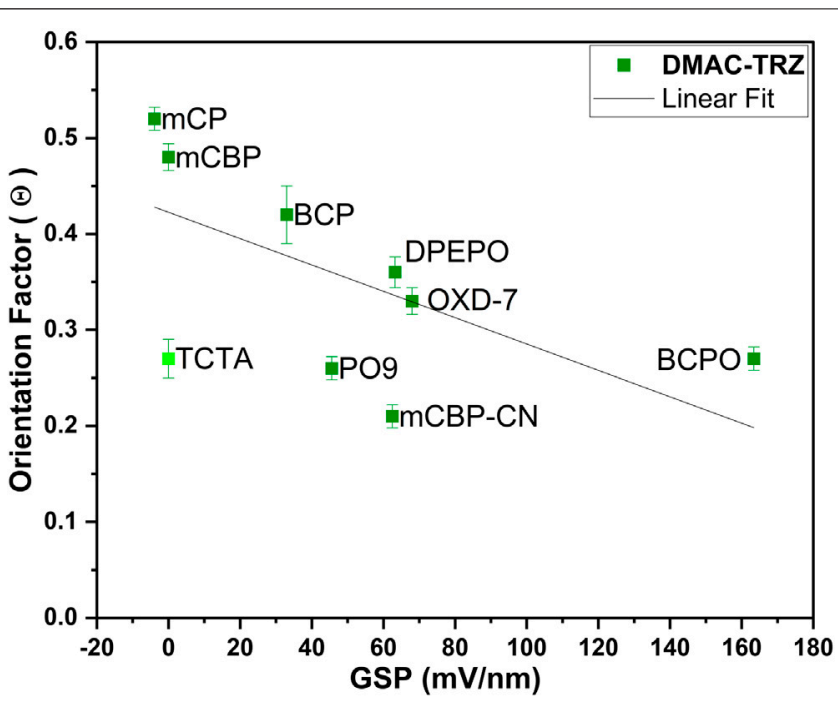

Figure 7 | (A) Dependency of the emitter's TDM orientation factor $(\Theta)$ vs. the GSP of the hosts with a linear fit. 


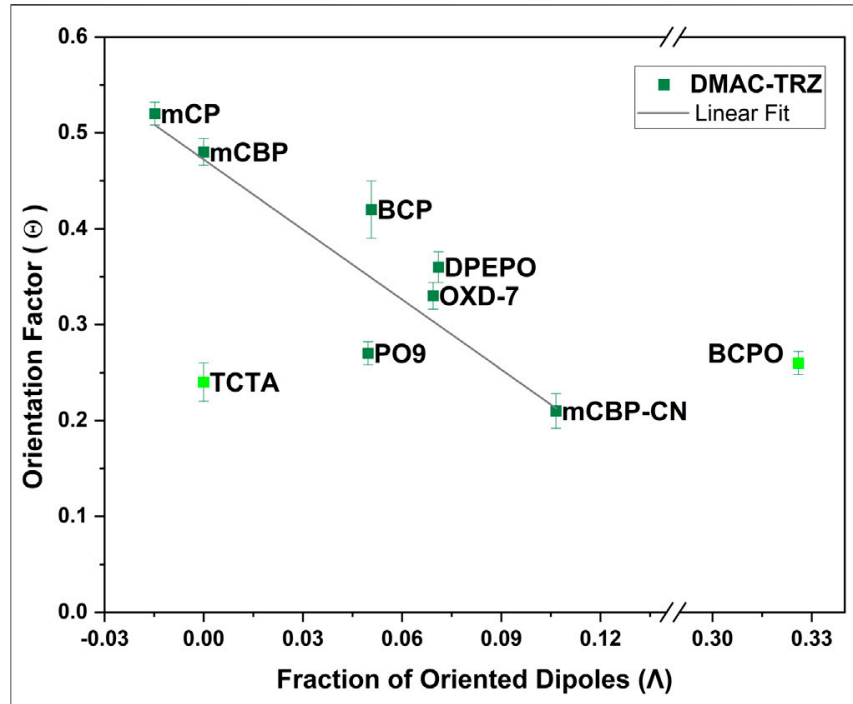

FIGURE 8 | (A) Dependency of emitter's TDM orientation factor $(\Theta)$ vs. the fraction of oriented PDMs $(\Lambda)$ of the hosts with a linear fit.

\section{SUPPLEMENTARY MATERIAL}

The Supplementary Material for this article can be found online at: https://www.frontiersin.org/articles/10.3389/fchem.2021.632639/ full\#supplementary-material.
TABLE 1 | Physical properties of host materials used in this study.

\begin{tabular}{|c|c|c|c|c|}
\hline Host & $\mathrm{T}_{\mathrm{g}}\left({ }^{\circ} \mathrm{C}\right)$ & PDM (D) & GSP $(\mathrm{mV} / \mathrm{nm})$ & $\begin{array}{c}\text { Degree of PDM alignment } \\
\Lambda\end{array}$ \\
\hline BCP & 62 & 2.8 & 33 & 0.050 \\
\hline $\mathrm{mCP}$ & 65 & 1.35 & -3.9 & 0.015 \\
\hline OXD-7 & 77 & 5.5 & 68 & 0.069 \\
\hline mCBP & 92 & 1.57 & 0 & 0 \\
\hline DPEPO & 93 & 5.5 & 61.7 & 0.071 \\
\hline $\begin{array}{l}\mathrm{mCBP}- \\
\mathrm{CN}\end{array}$ & 113 & 3.7 & 62.5 & 0.11 \\
\hline BCPO & 137 & 3.5 & 163 & 0.33 \\
\hline $\mathrm{PO}_{9}$ & 122 & 6.7 & 45.6 & 0.05 \\
\hline TCTA & 151 & 0 & 0 & 0 \\
\hline
\end{tabular}

The authors apologize for this error and state that this does not change the scientific conclusions of the article in any way. The original article and the Supporting Material have been updated.

Conflict of Interest: The authors declare that the research was conducted in the absence of any commercial or financial relationships that could be construed as a potential conflict of interest.

Copyright (c) 2021 Naqvi, Schmid, Crovini, Sahay, Naujoks, Rodella, Zhang, Strohriegl, Bräse, Zysman-Colman, Brütting. This is an open-access article distributed under the terms of the Creative Commons Attribution License (CC BY). The use, distribution or reproduction in other forums is permitted, provided the original author(s) and the copyright owner(s) are credited and that the original publication in this journal is cited, in accordance with accepted academic practice. No use, distribution or reproduction is permitted which does not comply with these terms. 